\title{
Biological Studies of Schizotetranychus lespedezae Beglyarov and Mitrofanov (Acari: Tetranychidae) on Pongamia pinnata (Milletia pinnata L.)
}

\author{
D. Devika Rani", D. Jemla Naik and K.S. Jagadesh \\ Department of Agriculture Entomology, MSSSOA, Parlakhemundi, Odisha \\ UAS, GKVK, Bangalore, India \\ *Corresponding author
}

\section{A B S T R A C T}

\section{Keywords}

Spider mites, Web mites,

Schizotetranychus lespedezae

Beglyarov\& MITROFANOV Pongamia, Milletia pinnata

Article Info

Accepted:

15 August 2019

Available Online:

10 September 2019
Schizotetranychus lespedezae Beglyarov and Mitrofanov (Acari: Tetranychidae) were recorded and described from the leaves of the Pongamia pinnata (Milletia pinnata L.) in UAS, GKVK, Bengaluru, the studies on Schizotetranychus lespedezae web mites depicts their unique aspects. Spider mites have become serious pests in agriculture and forestry, as a side-effect of the excessive use of artificial chemical compounds. Studies on this group have developed exponentially mainly because of their practical importance as pests. Mean no. of male off springs of $S$. lespedezae reproduced by each mated female was ranging from 1.72-3.28, with a mean of $2.50 \pm 0.78$ Mean no. of female off springs of S. lespedezae laid by each mated female mite was 26.72 \pm 5.77 (Range=20.95-32.49)

\section{Introduction}

Pongamia pinnata, commonly known as karanja is a leguminous oil yielding multipurpose tree., it can tolerate a range of different conditions with mean annual rainfall between $500-2500 \mathrm{~mm}$ and temperatures of 0 $-16^{\circ} \mathrm{C}$ minimum and $27-50^{\circ} \mathrm{C}$ maximum, mature trees can cope with light frosts, but require a dry period of 2-6 months (Duke, 1983; Daniel, 1997; Orwa et al., 2009).
Biochemical analysis of the mite-infested leaves revealed that there was a decrease in moisture content and chlorophyll content. Mite damage led to an increase in the total sugars and reducing sugars, total free amino acids, phenols, crude protein content and enzyme activities. However, phosphorus, potassium, secondary and minor nutrients were found to decrease due to mite feeding (Vishnupriya, 2016). Extensive surveys were carried out during 2016-2018, and collected 
mites of different families were identified. This paper reports on species of Schizotetranychus lespedezae Beglyarov\& Mitrofanov collected from the leaves of the Pongamia pinnata.

\section{Materials and Methods}

Collection, purification and mass culturing of web mite, Schizotetranychus lespedezae Beglyarov\& Mitrofanov under laboratory conditions

Mite infested leaves of Pongamia collected from ZARS, GKVK Campus, and surrounding areas of GKVK Bengaluru, were brought to the laboratory in separate polyethylene bags. Fifty females along with 1 to 2 attending males were randomly picked from infested leaf samples and transferred onto separate $2.5 \mathrm{~cm} \times 2.5 \mathrm{~cm}$ Pongamia leaf disks, placed on wet cotton wad in 6 inches Petri plates and allowed for colonization for at least 10 to 15 days. Excised leaf disk technique was followed for rearing and maintaining the mite culture in the laboratory. Later one female and one male from each of these leaf bits were slide mounted by using Hoyer's medium, composition: $15 \mathrm{~g}$ of gum arabic to $25 \mathrm{~mL}$ of $\mathrm{H}_{2} \mathrm{O}, 100 \mathrm{~g}$ of chloral hydrate and submitted for taxonomic identification at AINP, (Agricultural Acarology), Department of Agricultural Entomology, UAS, GKVK, Bengaluru. Leaf disks with S. lespedezae mite individuals were pooled and used as a pure starter culture for further culturing on Pongamia leaves placed on wet foam in polyethylene trays measuring $30 \mathrm{~cm} \mathrm{X} 25 \mathrm{~cm} \mathrm{X}$ $6 \mathrm{~cm}$ and the mite culture was used for various biological and toxicological studies (Milner, 1981).

\section{Development and reproduction of $S$. lespedezae}

The life history of $S$. lespedezae was studied twice, during October-November 2017, during which the temperatures of $25^{\circ} \mathrm{C}$ and relative humidity of 73-77 per cent was prevailing under laboratory conditions i.e. Initially a cohort of eggs laid on leaf disks measuring $5 \mathrm{~cm} \times 5 \mathrm{~cm}$ in two to four hours period were transferred individually by using fine camel hair brush on to 30 separate $2.5 \mathrm{~cm} \times 2.5 \mathrm{~cm}$ fresh Pongamia leaf disks, kept on wet cotton wad which were placed in polyethylene Petri plates having $6 "$ diameter $(\mathrm{n}=25)$.

The cotton wad was kept sufficiently moist by periodical wetting with clean water. Eggs on leaf disks were observed once in every 3 to 6 hours, under stereo binocular microscope, to record the development of the mite i.e., from incubation (egg hatching) upto adult emergence.

Duration of different developmental stages $v i z$. larva, quiescent-1 (larvo chrysalis), proto nymph and quiescent-2 (nympho chrysalis) were recorded. Developmental stages were transferred to fresh leaf disks as and when necessary or required and observations were continued. Other observations recorded with life history data included longevity of the adults (female and male) and sex of the emerging adult.

Results of web mite, Schizotetranychus lespedezae

\section{Egg to adult stage developmental parameters:}

Egg

Eggs are white in colour, transparent. Eggs hatched in 120.00 to 144.00 hours with a mean incubation period of 133.00 hours in both females and males (Table 1)

Larva

Larva have 3 pairs of legs,female larval duration lasted for 15.00-51.00 hours with a mean of $34.00 \pm 7.36$ hours, where as the male 
larva rested for 18.00-33.00 hours with a mean of $26.25 \pm 5.95$ hours (Table 1 ).

\section{Quiescent I}

The larvae underwent an inactive stage called as Quiescent I stage with mean duration of $20.00 \pm 5.07$ hours which ranged from 6.0030.00 hours in female. In male the Quiescent I stage was ranging from 15.00-39.00 hours, with a mean duration of $21.75 \pm 7.81$ hours (Table 1).

\section{Protonymph}

Protonymph could be distinguished from the larva in having four pairs of legs and no setae on trochanters. The female protonymph lasted for 9.00-36.00 hours with a mean of 26.23 \pm 5.23 hours. Male protonymph lasted for $18.00-$ 33.00 hours with a mean of $24.00 \pm 5.07$ hours (Table 1).

\section{Quiescent II}

Protonymph underwent an inactive stage called as Quiescent II stage which lasted for 12.00-39.00 hours in female, with a mean of $27.08 \pm 6.58$ hours. In male, Quiescent II stage ranged from 18.00-24.00 hours with a mean duration of $22.13 \pm 2.75$ hours (Table 1 ).

\section{Deutonymph}

Deutonymph could be distinguished from the protonymph by larger size and one seta on each of trochanters I-III, it also had four pairs of legs. The female deutonymph stage lasted for 18.00-39.00 hours with a mean of 27.46 \pm 4.33 hours. The male deutonymph stage lasted for 15.00-30.00 hours with a mean of $24.75 \pm$ 4.46 hours (Table 1 ).

\section{Quiescent III}

Deutonymph underwent Quiescent III stage, it is an inactive stage which lasts for21.00-33.00 hours in female with a mean of $26.77 \pm 2.42$ hours, in male Quiescent III stage was ranging from 24.00-30.00 hours, with a mean of 27.38 \pm 1.92 hours (Table 1 ).

\section{Adult}

Adult emerged after Quiescent III stage, it was an active stage. It differed from the deutonymph in size, one seta on each of trochanters I-III. In this stage one could easily identify the sexual dimorphism.

\section{Total developmental period}

Total developmental period was $294.46 \pm$ 11.88 hours in female and $279.25 \pm 14.49$ hours in male. Development from egg to adult in female occupied 15.00-30.00 days, with a mean of 12.27 days. In male it was ranging from $11.03-12.24$ days, with a mean of 11.63 days (Table 1).

\section{Reproductive parameters}

\section{Pre- oviposition period (days)}

Pre - oviposition period of web mite $S$. lespedezae on Pongamia ranged from 1.582.72 days, with a mean of $2.15 \pm 0.57$ days (Table 2).

\section{Oviposition period (days)}

The mated female had an oviposition period ranging from 10.28-16.58 days, with a mean of 13.43 \pm 3.15 days (Table 2).

\section{Post oviposition period (days)}

Post oviposition period of the female adult web mite ranged from 1.40-3.08 days, with a mean duration of $2.24 \pm 0.84$ days (Table 2).

\section{Longevity of mated female (days)}

Longevity of mated female of $S$. lespedezae was ranging from 13.62-22.02 days, with a mean of $17.82 \pm 4.20$ days (Table 2 ). 
Table.1 Development of web mite, Schizotetranychus lespedezae on Pongamia under laboratory conditions

\begin{tabular}{|c|c|c|c|c|c|}
\hline \multirow{3}{*}{\multicolumn{2}{|c|}{ Developmental Stage }} & \multirow{2}{*}{\multicolumn{2}{|c|}{$\begin{array}{l}\text { Mean duration of development (hours) } \\
\qquad \begin{array}{c}\text { Female } \\
(n=39)\end{array}\end{array}$}} & \multirow{2}{*}{\multicolumn{2}{|c|}{$\begin{array}{l}\text { Mean duration of development (hours) } \\
\qquad \begin{array}{c}\text { Male } \\
(n=8)\end{array}\end{array}$}} \\
\hline & & & & & \\
\hline & & Range & Mean & Range & Mean \\
\hline \multicolumn{2}{|l|}{ Egg } & $120.00-144.00$ & 133.00 & $120.00-144.00$ & 133.00 \\
\hline \multicolumn{2}{|l|}{ Larva } & $15.00-51.00$ & $34.00 \pm 7.36$ & $18.00-33.00$ & $26.25 \pm 5.95$ \\
\hline \multicolumn{2}{|l|}{ Quiescent I } & $6.00-30.00$ & $20.00 \pm 5.07$ & $15.00-39.00$ & $21.75 \pm 7.81$ \\
\hline \multicolumn{2}{|l|}{ Protonymph } & $9.00-36.00$ & $26.23 \pm 5.23$ & $18.00-33.00$ & $24.00 \pm 5.07$ \\
\hline \multicolumn{2}{|l|}{ Quiescent II } & $12.00-39.00$ & $27.08 \pm 6.58$ & $18.00-24.00$ & $22.13 \pm 2.75$ \\
\hline \multicolumn{2}{|l|}{ Deutonymph } & $18.00-39.00$ & $27.46 \pm 4.33$ & $15.00-30.00$ & $24.75 \pm 4.46$ \\
\hline \multicolumn{2}{|l|}{ Quiescent III } & $21.00-33.00$ & $26.77 \pm 2.42$ & $24.00-30.00$ & $27.38 \pm 1.92$ \\
\hline \multicolumn{2}{|l|}{ Total (hours) } & \multicolumn{2}{|c|}{$294.46 \pm 11.88$} & \multicolumn{2}{|c|}{$279.25 \pm 14.49$} \\
\hline \multirow[t]{2}{*}{ Development (egg to adult) } & Range & \multicolumn{2}{|c|}{$11.77-12.76$ days } & \multicolumn{2}{|c|}{$11.03-12.24$ days } \\
\hline & Mean & \multicolumn{2}{|c|}{ (12.27 days) } & \multicolumn{2}{|c|}{ (11.63 days) } \\
\hline
\end{tabular}


Table.2 Reproductive parameters of adult Schizotetranychus lespedezae on Pongamia under laboratory conditions

\begin{tabular}{|c|c|c|c|c|c|}
\hline Reproductive parameters & Range & Mean \pm S.D & \multirow[t]{2}{*}{ Mated female $(n=30)$} & \multirow[t]{2}{*}{ Range } & \multirow[t]{2}{*}{ Mean \pm S.D } \\
\hline Pre - oviposition period(days) & $1.58-2.72$ & $2.15 \pm 0.57$ & & & \\
\hline Oviposition period(days) & $10.28-16.58$ & $13.43 \pm 3.15$ & \multirow{2}{*}{$\begin{array}{l}\text { Mean no. of Eggs laid } \\
\text { by each mated female }\end{array}$} & \multirow{2}{*}{$\begin{array}{l}18.29- \\
30.03\end{array}$} & \multirow[t]{2}{*}{$24.16 \pm 5.87$} \\
\hline Post - oviposition & 1. & & & & \\
\hline $\begin{array}{l}\text { Longevity of mated female } \\
\text { (days) }\end{array}$ & $13.62-22.02$ & $17.82 \pm 4.20$ & $\begin{array}{l}\text { Mean no. of female off } \\
\text { springs reproduced by } \\
\text { each mated female }\end{array}$ & $\begin{array}{l}20.95- \\
32.49\end{array}$ & -5.77 \\
\hline Long & 2.8 & & \multirow{2}{*}{$\begin{array}{l}\text { Mean no. of male off } \\
\text { springs reproduced by } \\
\text { each mated female }\end{array}$} & \multirow{2}{*}{$\begin{array}{l}1.72- \\
3.28\end{array}$} & \multirow[t]{2}{*}{$2.50 \pm 0.78$} \\
\hline $\begin{array}{l}\text { Longevity of unmated female } \\
\text { (days) }\end{array}$ & 13.44 & 18.12 & & & \\
\hline $\begin{array}{l}\text { Mean no. of eggs laid by each } \\
\text { unmated female }(n=30)\end{array}$ & $22.61-36.59$ & $29.60 \pm 6.99$ & $\begin{array}{l}\text { Sex ratio of the } \\
\text { Progeny }(\hat{0}: \text { o })\end{array}$ & \multicolumn{2}{|c|}{ 1.00: 10.69} \\
\hline
\end{tabular}

N.B.: Unmated females produced only male off springs; Mated females produced both male and female off springs

\section{Longevity of male (days)}

Longevity of adult male of $S$. lespedezae was ranging from 2.84-6.46 days, with a mean of $4.65 \pm 1.81$ days (Table 2).

\section{Longevity of unmated female (days)}

Longevity of unmated adult female was ranging from 13.44-22.80 days, with a mean of $18.12 \pm 4.68$ days (Table 2 ).

Mean no. of eggs laid by each unmated female

Each unmated female laid more no. of eggs, ranging from 22.61-36.59, with a mean of $29.60 \pm 6.99$ as compared to the mated female (Table 2).

Mean no. of Eggs laid by each mated female

The number of eggs laid by each mated female was lesser ranging from 18.29-30.03 eggs, with a mean of $24.16 \pm 5.87$ (Table 2).

Mean no. of female off springs laid by each mated female

Mean no. of female off springs of $S$. lespedezae laid by each mated female mite was 26.72 \pm 5.77 (Range $=20.95-32.49) \quad$ (Table 2).

Mean no. of male off springs laid by each mated female

Mean no. of male off springs of S. lespedezae reproduced by each mated female was ranging from 1.72-3.28, with a mean of $2.50 \pm 0.78$ (Table 2).

Sex ratio of the progeny $(0:$ : + )

The progeny of mated females comprised of more number of females as compared to the male progeny (male: female sex ratio 1:10.69) (Table 2).

\section{References}

1.Daniel JN, Pongamia pinnata - a nitrogen fixing tree for oilseed ${ }^{\text {ee }}$ NFT Highlights, NFTA, Fact Net, Winrock International., 1997.

2.Duke JA, Handbook of energy crops, unpublished, http://www.hort.purdue.edu/newcrop/du ke_energy/Pongamia pinnata.html., 1983. 
3.Helle W, Overmeer WPJ. Variability in tetranychid mites. Annual Review of Entomology., 1973; 18: 97-120

4.Jeppson LR, Keifer HH. Baker EW Mites Injurious to Economic Plants. University of Calfornia Press, Berkeley, CA, USA. 1975.

5.Mitchell R. Growth and population dynamics of a spider mite (Tetranychus urticae K., Acarina: Tetranychidae). Ecology., 1973; 54: 1349-1355

6.orwa C, Mutua A, Kindt R, Jamnadass R, Simons A. Agro forestry databse: A tree reference and selection guide version 4.0. 2009.

7. Potter DA, Wrensch DL, Johnston DE.
Guarding, aggressive behavior, and mating success in male two-spotted spider mites. Annals of the Entomological Society of America., 1976; 69: 707-711.

8.van de Vrie M, McMurtry JA, Huffaker CB. Ecology of tetranychid mites and their natural enemies: a review. III. Biology, ecology and pest status, and host plant relations of tetranychids. Hilgardia., 1972; 41: 343-432.

9.Vishnupriya R. Biochemical changes induced in Pongamia leaves by eriophyid mite Aceria pongamiae. International Journal of Current Research., 2016; 8(12): 43497-43500.

\section{How to cite this article:}

Devika Rani, D., D. Jemla Naik and Jagadesh, K.S. 2019. Biological studies of Schizotetranychus lespedezae Beglyarov \& Mitrofanov (Acari: Tetranychidae) on Pongamia pinnata (Milletia pinnata L.). Int.J.Curr.Microbiol.App.Sci. 8(09): 684-689.

doi: https://doi.org/10.20546/ijcmas.2019.809.081 